\title{
Constructive Patriotism in Wartime
}

\author{
Eyal Lewin \\ Department of Political Science, Ariel University, Ariel, Israel \\ Email: lewin1212@gmail.com \\ Received June $15^{\text {th }}$, 2013; revised July $22^{\text {nd }}, 2013$; accepted August $6^{\text {th }}, 2013$
}

\begin{abstract}
Copyright (c) 2013 Eyal Lewin. This is an open access article distributed under the Creative Commons Attribution License, which permits unrestricted use, distribution, and reproduction in any medium, provided the original work is properly cited.
\end{abstract}

\begin{abstract}
As opposed to blind patriotism, a moderate form of constructive patriotism has been depicted in previous research and empirically observed. The major distinction between blind patriotism and constructive patriotism lies in the latter's capacity for criticism. Our research suggests, however, an additional distinction dividing constructive patriotism into two forms: one form is capable of practical judgment (hence, political constructive patriotism), and the other form is critical on grounds of ethical issues (hence moral constructive patriotism). This study then seeks to examine which sort of patriotism prevails within society during wartime; of special interest, for that matter, are the suggested variations of constructive patriotism. Two diverse cases have been chosen in order to examine the reactions within a democratic society: The American case of the 2003 invasion of Iraq and the Israeli case of the 2006 war in Lebanon. A substantive content analysis has been employed, surveying social processes through a variety of articles in an American and an Israeli daily newspaper. The findings reveal that in both cases among expressions of constructive patriotism, those of political constructive patriotism form a vast majority and only a few of them express moral constructive patriotism. It therefore seems that constructive patriots are not necessarily as moral as they might seem to be at first glance, even though they criticize state and society. The case of war in particular proves how on moral grounds criticism is important, but not enough.
\end{abstract}

Keywords: Patriotism; Blind Patriotism; Constructive Patriotism; Nationalism; Morality in War

\section{Introduction: Ear Witness in Metulla}

July 2006 was no easy time for Israel, certainly not for its north borderline inhabitants: thousands of rockets were launched towards the villages, many of them hitting built-up areas. On the other side of the border, inside southern Lebanon, IDF soldiers were fighting against Hezbollah guerrilla fighters, and the thunder of combat was to be heard every once in a while, day and night. Choppers flying to and fro across the border were constant evidence of injured soldiers being urgently delivered to hospitals. This of course was not the first war this country had known, but perhaps for the first time after many years Israeli army forces were encountering a highly motivated and professionally trained enemy, and Israeli civilians had to experience daily exposure to the hazards of rocket artillery.

Then, quite suddenly, a ceasefire was achieved and one summer morning not a single shot was to be heard. The fires that had burned houses after rocket hits, the sirens of ambulances and security forces, the sites of death and destructionall these were replaced in an instant by the tranquility of peace. That was what the day after the war was like. The pastoral views of the beautiful northern countryside revealed nothing of what had been taking place there only hours before.

As night was falling, the first IDF troops to be relieved returned from Lebanon, gathering in the border-straddling village of Metulla. It was there, in Metulla, that I first met the reserves soldiers who were bitterly criticizing the conduct of war. They sat together in circles, talking and sharing their experience; small circles and large ones, one unit circles and mixed unit ones; some were speaking harshly and others were calm, some were bursting and others were silent. Metulla, a small tourist village in normal times, was now flooded with soldiers assembling in small groups and talking into the night. Being a political sociologist I could not resist the temptation and I joined the circles, every once in a while switching from one huddle to another, wearing my ears out. The soldiers were mainly angry about inconsistent commands and contradicting orders that cost the lives of their comrades. I was particularly attracted to one artillery unit whose captain told me how he ran out of ammunition just as an infantry squad needed his assistance so badly.

In Metulla, I was witnessing the beginning of a civic protest led by reserves soldiers; these were people who last night were willing to fulfill the call of duty and sacrifice life for their country, and tonight were persistently speaking about a modern democratic storming of the Bastille. In political science those people are referred to as constructive patriots.

\section{Blind Patriotism versus Constructive Patriotism}

Patriotism is generally considered to be love of country, love of fellow countrymen, love of birthplace, and deep feelings for the local sights that one encounters all his life, forming a natural personal family-like connection to a specific country (Schaar, 1981; Viroli, 1995). This patriotic affection proves to be stronger than any moral idea of justice and it is the core of the patriot's motivation to pay personal prices that rise far above any expectation (Oldenquist, 1982). Patriotism often re- 
lates to the republican approach, according to which as a civil virtue we owe our lives, our education, our culture and our freedom to our country (Viroli, 1995). Traditionally, being a war hero has always been the ultimate expression of love for country, since the battlefield had formed an arena where logic and personal needs may yield to self sacrifice. No wonder, therefore, that obeying the call of duty, even when it means risking one's life, has frequently been the definition of patriotic devotion (Sommerville, 1981). Perhaps the outstanding expression of this attitude was Stephen Decatur's famous declaration: "Our Country! In the intercourse with foreign nations may she always be right, but our country, right or wrong!” Nevertheless, an altogether different comprehension of patriotism has its roots as early as George Bernard Shaw's mockery of the famous quotation, rephrasing it as "My mother, drunk or sober!" Elaborating on this, the liberal conception of state and its institutions as merely agents of the country that have taken some instrumental authority would go one step further in expressing Shaw-like cynicism: "My mother's lawyer, drunk or sober”. As opposed to the conventional blind patriotism, this other voice does not deny the human capacity for loyalty and love of country, but it demands that citizens not be deprived of life when justice or logic finds no sense in ending it. According to this mindset, one ought to object to the mistakes that governments make; loyalty to one's country-just like love of one's own mother-may require personal criticism, disobedience, and at times_obstinate resistance (Sommerville, 1981). These are the moral grounds on which a distinction has been made between blind patriotism with its all-encompassing demands and a moderate form of patriotism characterized by continual judgment. The moderate shape of patriotism does not deny patriotism as a virtue as long as the patriotic activity does not encourage immoral actions (Nathanson, 1989). The moderate patriotism has been deeply examined and empirically tested in The United States, England and Germany. More often referred to as constructive patriotism, the following observations have been made (Schatz, Staub, \& Lavine, 1999; Blank \& Schmidt, 2003; Rothi, Lyons, \& Chryssochoou, 2005):

1) Blind patriotism resents any form of criticism towards the country; constructive patriotism is manifested through questioning whether the patriotic action fits the social group's goals.

2) Blind patriotism is characterized by political disengagement and deliberate political ignorance; constructive patriotism correlates with gathering of information, striving for social conclusions, and high levels of political involvement.

3) Blind patriotism is strongly connected with nationalism and with a sense that the national security-indeed, the national culture itself-is at risk; constructive patriotism may put national identity aside and even deny feelings of national superiority.

4) Blind patriotism defines social attachment using a terminology of genealogy and primordial origins generated within the nation's history; constructive patriotism forms social boundaries through civic procedures and commonly shared political structures.

\section{Political Constructive Patriotism versus Moral Constructive Patriotism}

The nature of criticism that characterizes constructive patriotism is not entirely clear. On July $20^{\text {th }} 1944$ Ludwig Beck, a former high ranked German general, led an unsuccessful plot against Hitler. This was not the first time that he was involved in a conspiracy against the Furher: a year before he led two other abortive attempts to assassinate the Reichskantzler. Indeed, ever since his demonstrative resignation from a leading military position in 1938 Beck was pushing against the leadership of the Third Reich, a struggle at the end of which he was executed. Surely a German General who unlike many others had opposed Hitler and had risked his life time and again to overthrow the Nazi Regime could be counted as a German patriot of the criticizing nature. Yet an additional inquiry into Beck's criticism reveals that he was mainly concerned with military matters rather than moral issues: He resigned from the army before World War II broke out because he believed that the English and French response to Hitler's conquest of Czechoslovakia would lead to warfare that he thought the Wermacht was incapable of coping with. Another leading participant in the 1944 abortive putsch was Claus von Stauffenberg, who unlike Beck had been deeply angered by the growing systematic maltreatment of Jews and suppression of religion by the Third Reich (Shirer, 1964; Hoffmann, 1996). Both of these German General demonstrated constructive patriotism, both of them executed actions of utmost personal bravery, proving true love for their country and people; but whereas Beck had criticized Hitler for his policy von Stauffenberg had resented him on moral grounds.

Picking a more recent example to illustrate this point, on July $6^{\text {th }} 2003$, four months after the invasion of Iraq began, a retired diplomat of the United States Foreign Service, Joseph Wilson, published an article in the New York Times titled "What I Didn't Find in Africa". Wilson accounted his trip to Niger a year before in which he was to inquire into whether or not Saddam Hussein had purchased enriched uranium there. In the New York Times publication Wilson accused President Bush of exaggerating the Iraqi threat in order to justify war. Indeed, on several occasions various officials in the Bush administration admitted having based accusations of Iraqi leadership on faulty intelligence and inaccurate information. Following Wilson's public announcements an intentional leak to the press exposed Wilson's wife, Valerie Plame, as a CIA employee, a revelation that ended her career (Wilson, 2005; Tenet, 2007). Was Joseph Wilson a whistleblower, putting his reputation at risk and endangering his wife's career for the sake of truth? Was Wilson a patriotic citizen unraveling in public how the Bush administration had pressed for war no matter what the facts had been? This is one possibility supported by his autobiography. His opponents, however, point out that Wilson had always been a Democrat who resented the Republican administration and by the time he presented his findings in public he was already an active John Kerry supporter. Perhaps, then, the whole affair was nothing but a case of a partisan trying to discredit his political rivals in an election campaign? The Rashomon effect leaves us with merely ambiguous answers so that the truth may remain forever obscure. Nevertheless, even though in both versions a loyal citizen publicly criticized his President for misleading the people, for Wilson's supporters he was a proper patriot while for his adversaries he was nothing of the kind.

It follows that the distinction between two forms of patriotism, blind and constructive, might not be enough, and it is therefore suggested that cases of constructive patriotism be sorted into two different groups

a) Political constructive patriotism: a patriotic action in which criticism is involved yet is based on an underlying moti- 
vation that has nothing to do with issues of ethics or morality.

b) Moral constructive patriotism: a patriotic action in which criticism is involved, revealing passion for values of justice and fairness.

\section{Background for the Case Studies}

The two case studies that have been chosen for this research are diverse ones, leaving little room for comparison: The American 2003 invasion of Iraq and the Israeli 2006 war in Lebanon. One is the case of a world superpower behaving like the savior of Western culture with its troops acting thousands of miles away from home; the other is a case of a small, yet powerful, country adopting a narrative of struggling for its existence against its enemies next door.

The American case of the 2003 war in Iraq is the case of a democratic society experiencing large scale overseas fighting. The war in Iraq, codenamed Operation Iraqi Freedom but perhaps more often referred to as the Second Gulf War, began on March 20, 2003, when a largely British and American force supported by small contingents from Australia, Denmark and Poland invaded Iraq. Saddam Hussein's army was quickly overwhelmed; on April $9^{\text {th }}$ Baghdad fell to US forces; on April $13^{\text {th }}$ Tikrit-Hussein's hometown - was taken by the Marines; by mid-April American infantrymen had seized the deserted Baath Party ministries and coalition partners had claimed that the war was effectively over. On May $1^{\text {st }} 2003$ President Bush staged a dramatic visit to the aircraft carrier Abraham Lincoln where he announced that the war's mission had been accomplished. By the end of this major combat phase, between March $20^{\text {th }} 2003$ and May $1^{\text {st }} 2003,139$ American military personnel had been killed as well as 33 British soldiers. On the Iraqi side approximately 9000 combatants and 7300 civilians had been killed.

The causes and consequences of the war remain controversial. The basic grounds for invading Iraq as offered by President Bush had been Iraq's development of weapons of mass destruction posing a threat to the United States and its allies. It has also been claimed that Saddam Hussein had been collaborating with the Al-Qaeda terrorist group. However, after the invasion no evidence was found of either mass destruction weapons or substantial Al-Qaeda connections. The main American rationale for launching the war has therefore faced heavy criticism from an array of popular and official sources both inside and outside the United States. Years after the successful invasion, all attempts to restore order in Iraq have failed, a growing number of coalition nations have withdrawn their troops, and many critics rail against the high human and financial costs of the ongoing war as well as its moral ramifications.

The Israeli case of the 2006 war in Lebanon enables us to examine firsthand the reactions within a democratic society conducting modern warfare close to its borders. Regarding Israel as a case study has some important advantages, since Israeli society has been going through certain processes extensively that make it almost a living laboratory: Technological development, changes towards a capitalistic market, large scale absorption of immigrants and a constant war involving all layers of society-all these have the capacity to turn empirical findings and conclusions into basic data for further comparative studies (Rebhun \& Waxman, 2003). War in Lebanon started on July $12^{\text {th }} 2006$ when Hezbollah fired rockets and mortars at Israeli border villages, diverting attention from one of its units that had crossed the border, kidnapped two Israeli soldiers and killed three others. Israeli troops immediately attempted to rescue the abducted soldiers but were unsuccessful, losing five more soldiers. Israel responded with massive air strikes and artillery fire on Lebanese targets, damaging mainly civilian infrastructure. Hezbollah then launched more rockets into northern Israel. Israel in turn increased the bombardment of Lebanon and eventually invaded its southern parts. For over a month Hezbollah hit Israeli cities time and again, and for the first time in decades engaged the IDF in guerrilla warfare from hardened positions inside Lebanon. The Israeli government had declared that the object for entering the war was to retrieve the abducted soldiers and to destroy the military capability of Hezbollah; however, cutting the losses led the Israeli administration to approve a United Nations resolution, to agree to a ceasefire and to withdraw all its forces from Lebanon before its announced goals could be achieved. During this war over a thousand Lebanese civilians were killed and the estimate of Hezbollah's losses reached several hundred warriors. On the Israeli side 43 civilians and 119 soldiers were killed. The disproportionate death toll, however, should take into account the availability of warning systems and bomb shelters throughout northern Israel and the fact that more than 350,000 of its inhabitants had been evacuated.

Israeli political leadership has been insisting ever since the war ended that the military operation altered the regional strategic balance and that the goals of war were successfully attained. However, demobilized reserve soldiers, parents of soldiers killed in the fighting, and groups of citizens who demand governmental accountability have conducted protests against the Israeli political and military leadership. Unable to further whitewash the many failures, the Israeli government has formed an investigation commission headed by a retired judge, whose announced mandate was to inquire into the authorities' conduct before, during and in the aftermath of the war.

\section{Research Conduct}

The measurements that differentiate between forms of patriotism are not always crystal clear (Huddy \& Khatib, 2007). Notwithstanding these certain flaws, and considering criticism to be the core characteristic of constructive patriotism, this study seeks to examine which sort of patriotism prevails within society during wartime; of special interest as well are the different variations of constructive patriotism.

Blind patriotism may be badly needed in order to enroll citizens in an ongoing large scale operation, but what kind of constructive patriotism can be found in a recruited society? Would it be political constructive patriotism nourished by skepticism together with the growing costs of warfare, or should we expect to find moral constructive patriotism fueled by scenes of horror and human destruction?

In order to further inquire into the occurrence of patriotism, a substantive content analysis was employed, surveying social processes through commentaries in newspapers. The semiotic approach that underlies this methodology facilitates a deep understanding not only of the specific text under inquiry but also of the social structures and institutions the text might represent (Slater, 1998; Jupp, 1996; Jupp \& Norris, 1993). Inquiry into the American case was made through the relevant issues of The New York Times, referring to it as the largest metropolitan newspaper in the United States and as an internationally dis- 
tributed daily newspaper. Having won some 94 Pulitzer prizes and having traditionally printed full transcripts of major debates, the New York Times seems to need no additional advocacy as a leading newspaper to be chosen for this research. The daily issues that were picked for inquiry were those published during the first phase of the war, from March $20^{\text {th }} 2003$ (the day the invasion started) through May $2^{\text {nd }} 2003$ (one day after President Bush's declaration on board the Abraham Lincoln that the mission had been accomplished).

In order to inquire into the Israeli case, Haaretz Hebrew daily newspaper was chosen as the best potential site for the expression of constructive patriotism because of its capacity for criticism: Its political allegiance is that of liberal conservatism; it is a strong supporter of territorial concessions in the context of Israeli politics, yet it is open to a wide variety of political opinions in its op-ed pages. The daily issues that have been picked for inquiry are those published during the war, from July $13^{\text {th }}$ 2006 (a day after the war broke out) through August $14^{\text {th }} 2006$ (one day after the ceasefire took place).

In both cases, that of the New York Times and that of Haaretz, the text analysis concentrated on quotations of political commentary, editorial annotations, and political or economical columns from all the news desks. Once the relevant articles were chosen, they were categorized into three significant groups. Classifying the articles according to their meaning in the context of patriotism allowed further comparison of texts -qualitative and quantitative (Strauss \& Corbin, 1998; Arsky \& Knight, 1999). The three categories and their subtexts extracted from the articles are as follows.

\section{Blind patriotism}

a) Support of the political and military leadership. Major themes in the American case: praising the Joint Forces Command and the way it led the war; strong belief in the abilities of American military; justifying questioned military actions based on the assumption that authorities know what they are doing due to confidential intelligence.

Major themes in the Israeli case: calling for an annihilation of the enemy; advising the government to hit the Hezbollah as painfully as possible.

b) Support of fighting. Major themes in the American case: condemning any protest or war objection as long as fighting goes on; opposing any form of criticism and boycotting radio stations, news networks and celebrities who criticize the war openly; willingness to continue the war even if its prices rise.

Major themes in the Israeli case: scorning the media and calling for its restraint; opposing any form of criticism; calls for symbolic actions such as flying flags; encouraging the leadership to continue even if the prices of war rise.

c) Moral and logical justification of the war. Major themes in the American case: belief in the war's goals of disarming Iraq and transforming it into a democracy; comprehending war in Iraq as part of a global battle against Al-Qaeda's terror; perceiving America's international role as having to police the world, pre-emptive strikes against totalitarian regimes being just part of that role; stressing Saddam Hussein's evilness and comparing him to Hitler.

Major themes in the Israeli case: stating how the goal of fighting was defending Israel; commenting on the high moral spirits of the IDF; comparing the present confrontation to previous conflicts when Israel had been attacked.

\section{Political constructive patriotism}

a) Fear for the consequences of warfare. Major themes in the American case: war in Iraq breeds terrorism and strengthens Al-Qaeda's recruiting abilities; more terror attacks on the US are expected as one of the consequences of war; if the US turns Iraq into a mess, the whole world will turn against America; high levels of concern for the fate of close friends and relatives who serve in Iraq.

Major themes in the Israeli case: Syria joining and fighting alongside with the Hezbollah; the kidnapped Israeli soldiers being harmed; destruction of future tourism in Israel; comparisons to the American experience in warfare such as Vietnam, Somalia or Iraq.

b) Cost effect balancing. Major themes in the American case: economic hardships and the financial costs of war; the costs of war dictate unwanted priorities and neglect of serious American welfare projects, as war drains resources from essential American institutions; disregarding international opinion and acting unilaterally harms long-term US interests, since friends around the world are being neglected, potential allies are being abandoned, and when Arab pride is being offended even moderate countries such as Turkey turn against America.

Major themes in the Israeli case: weighing losses versus accomplishments; calling for additional long term political goals beyond the ones the war may never achieve.

c) Disapproval of leadership. Major themes in the American case: lack of belief in the war's goals as promoted by the administration, and a deep sense that the war is merely about power and greed-private interests in the oil market, in selling weapons, and in profiting from the construction of post-war Iraq; proposing that the motivation for war lies in Bush's personal psychological need to prove his ability to complete his father's mission; criticizing the strategy and military tactics of American high command; skeptically viewing post-war policies and futile attempts to restore order once the invasion turns into occupation.

Major themes in the Israeli case: condemning governmental bureaucracy for its inability to properly cope with the situation; expressing disappointment in army operations; criticizing military and political leadership by pointing out their failures.

d) Lack of democratic procedures. This subtext is to be found only in the American case, and its major themes are: there has never been a declaration of war by the congress; no open debate or dialogue has ever taken place and the elected leadership has systematically ignored public opinion.

\section{Moral constructive patriotism}

a) Valuing peace. Major themes in the American case: war is illegal and immoral, and therefore ought to be perceived as a defeat for humanity; pre-emptive war in the name of peace contains an inherent contradiction.

Major themes in the Israeli case: opposing the very act of managing conflicts through violence; rejecting expressions of belligerence and aggressiveness; accusing Israeli leadership of arrogance.

b) In quest of justice. Major themes in the American case: condemning death of innocent women and children; condemning violation of civic liberties; adapting a narrative according to which America is the aggressor since Iraq had never intended to attack the US nor had it ever posed a threat to international peace and security.

Major themes in the Israeli case: viewing the damage that Israel has caused in Lebanon as immoral and disproportionate; calling Israeli leadership to assist Lebanon in its rehabilitation.

c) Religious objection. This subtext is to be found only in the American case, and its major theme is objecting to war 
using religious terminology, such as claiming that war is opposed to Christianity or that any killing is against God's will.

\section{Findings}

Screening the diverse articles in the New York Times issues that had been published throughout the first phase of the 2003 war in Iraq, 284 relevant citations expressing different kinds of patriotism have been found and reviewed. The quantitative examination of the three categories of patriotism has revealed the following proportions.

Blind patriotism: 87 citations, forming $30.6 \%$ of all the chosen expressions.

Political constructive patriotism: 174 citations, forming $61.3 \%$ of all the chosen expressions.

Moral constructive patriotism: 23 citations, forming $8 \%$ of all the chosen expressions.

Subtexts within each category in the American case have been found to be as follows.

\section{Blind patriotism}

a) Support of the political and military leadership: 15 citations.

b) Support of fighting: 31 citations.

c) Moral and logical justification of the war: 41 citations.

\section{Political constructive patriotism}

a) Fear of the consequences of warfare: 22 citations.

b) Cost-effect balancing: 55 citations.

c) Disapproval of leadership: 80 citations.

d) Lack of democratic procedures: 17 citations.

3. Moral constructive patriotism

a) Valuing peace: 5 citations.

b) In quest of justice: 11 citations.

c) Religious objection: 7 citations.

Examining the varied articles in Haaretz issues that were published throughout the 2006 war in Lebanon, 203 relevant citations expressing different kinds of patriotism have been located and reviewed. The quantitative examination of the three categories of patriotism has uncovered the following proportions.

Blind patriotism: 72 citations, forming 35\% of all the chosen expressions.

Political constructive patriotism: 113 citations, forming 56\% of all the chosen expressions.

Moral constructive patriotism: 18 citations, forming 9\% of all the chosen expressions.

Subtexts within each category in the Israeli case have been found to be as follows.

\section{Blind patriotism}

a) Support of the political and military leadership: 18 citations.

b) Support of fighting: 41 citations.

c) Moral and logical justification of the war: 13 citations.

2. Political constructive patriotism

a) Fear of the consequences of warfare: 11 citations.

b) Cost-effect balancing: 38 citations.

c) Disapproval of leadership: 64 citations.

3. Moral constructive patriotism

a) Valuing peace: 8 citations.

b) In quest of justice: 10 citations.

\section{Discussion}

A comparative project, which is beyond the scope of this re- search, may find various similarities as well as differences between the two chosen cases-the American and the Israeli patriotic public expressions during warfare. However, above allthe two diverse case studies are comparable in the sense that in both of them the distribution of the types of patriotic expressions resembles each other, creating a uniform pattern: The investigation of the two diverse case studies shows that the proportional differences between the types of patriotism are to an extent consistent. In both cases, blind patriotism forms about a third of the total number of articles that were reviewed. Considering the fact that all of the articles were published during wartime, on the face of it one might find those occurrences of blind patriotism to be quite few. However, since the focus of this research was constructive patriotism, the choice was made to deliberately explore newspapers that stand for criticism even in times of emergency. Other newspapers, as well as public polls, probably would have led to other results that are outside the scope of this specific inquiry.

Within constructive patriotism, in both case studies apparently only $12 \%-14 \%$ of the cites have proved to be instances of moral constructive patriotism, whereas the remaining $86 \%$ $88 \%$ represent political constructive patriotism. The fact that the vast majority of expressions are those of political constructive patriotism leaves us with something to brood over: it seems that constructive patriots are not necessarily as moral as they might seem to be at first glance: $55 \%$ of the political constructive patriotism cites in the American case and $56 \%$ of the political constructive patriotism cites in the Israeli case criticize the way the leadership had run the war regardless of its moral consequences (the American case includes, for that matter, 10\% of the political constructive patriotism cites that base their mistrust in the leadership on alleged non-democratic behavior). About one third of the political constructive patriotism cites$32 \%$ in the American case and 34\% in the Israeli case-represent cost-effect arguments that are not necessarily connected with any plea for ethics. The remaining $13 \%$ of the political constructive patriotism cites in the American case and 10\% in the Israeli case represent no more than a selfish fear (although in some cases a collective one) of the devastating results of the fighting. These findings become even more disturbing when data indicate that in fact it is blind patriotism that proves to be based on moral grounds: $47 \%$ of blind patriotism cites in the American case support the war using moral claims concerning the justification of war; the Israeli case falls short with only $18 \%$ of blind patriotism cites that are supposed to be morally supportive of the war. Could it be, then, that defenders of blind patriotism are more concerned with ethics than those encouraging constructive patriotism? Before a positive answer to that is hastily given, one should consider not only the number of cites but also their content: In the American case some of the expressions of blind patriotism's support for fighting are, for example, burning records of famous artists who have dared to speak against the war, and in the Israeli case some of the arguments for blind patriotism's support for fighting are consist of calls to teach the Arabs a lesson they would never forget-not necessarily justifications founded on highly moral grounds. Still, one can hardly ignore the fact that the claims for blind patriotism searching for moral justification outnumber those of constructive patriotism.

Poking and prodding into moral constructive patriotism reveals that a large majority of the citations representing moral constructive patriotism indeed express upset over the moral 
ramifications of war: $78 \%$ in the American case, counting the religious opposition to war as an ethical one, and $56 \%$ in the Israeli case. However, without under-evaluating the remaining moral constructive patriotism cites that support peace as a state of mind ( $22 \%$ in the American case and $44 \%$ in the Israeli case), the meaning of this data is that the moral demand to take into consideration basic human ethics forms as little as $6 \%$ at best out of the entire number of cites, and no more than $16 \%$ of the constructive patriotism cites. Overall, then, the figures point out quite clearly that very much like blind patriotism, constructive patriotism based on criticism of authority-namely political constructive patriotism - might fail to be based on moral standards.

Much of the interpretation that lies at the core of this research is debatable. One might argue, for example, that opposing the war due to great concern for the fate of close friends and relatives who serve in Iraq is an opposition based on solid moral grounds and therefore should not necessarily be counted as political constructive patriotism but rather as moral constructive patriotism. To choose another example, one might also see as moral constructive patriotism the objection to war for fear of losing financial resources that were originally intended for the war against poverty. These different interpretations are bound to lead to different analyses of the very same data and therefore to different conclusions. Nevertheless, even if the mathematics of a different understanding of data might produce slightly different results from those presented in this paper, surely the logic of this study remains clear and stable, at least throughout the two chosen case studies: During wartime, the vocabulary of constructive patriotism in democracy may form a major component of patriotic expressions, yet moral and ethical thought during wartime are unfortunately scarce-by any measure, too scarce, even among the critics of violence.

\section{Conclusion}

During the final 10 days of the 2006 war the MLRS (Multiple Launch Rocket System) was used to a great extent by Israeli artillery forces. MLRS rockets are designed to burst into submunitions in order to blanket enemy army and personnel on the ground with smaller explosive rounds. The use of this weaponry is controversial mainly due to its inaccuracy; in order to compensate for the inability to strike individual targets precisely, IDF units have "flooded" the battlefield with munitions: as many as 1800 cluster bombs were launched, containing over 1.2 million cluster bomblets. The sub-munitions that had not detonated on impact, estimated at $40 \%$ of those fired in Lebanon, remained on the ground unexploded, effectively littering the landscape with thousands of land mines which would continue to claim victims long after the war had ended (Tice, 2008). Had any of the artillery commanders, who had proved themselves in Metulla to be constructive patriots, shot MLRS rockets? Unfortunately the answer to that is most likely positive, and for all we know none of them had ever objected to doing so in real time. In the Metulla circles there has been much dismay about the conduct of war, much criticism of military and civilian leadership, but no claims against the moral implications of having trigger-happily launched the MLRS sub-munitions. As the comparative empiric data of this research reveal, Israeli society is probably no better or worse than any other society experiencing the stress of war. It is precisely for this reason that the low levels of moral commitment among constructive patriots should alarm worldwide advocates of democracy. The bitter soldiers gathering in Metullah on August $14^{\text {th }} 2006$ were not killers nor were they vicious bandits searching for revenge. They were patriotic citizens who had been called for duty and had willingly fought for their country; they were also involved citizens demanding full answers from a leadership that they felt had let them down. They were, according to this description, constructive patriots criticizing the state. But as the casualties of war prove-criticism is not enough.

\section{REFERENCES}

Arskey, H., \& Knight, P. T. (1999). Interviewing for social scientists: An introductory resource with examples. London: Sage.

Blank, T., \& Schmidt, P. (2003). National identity in a united Germany: Nationalism or patriotism? An empirical test with representative data. Political Psychology, 2, 289-312. http://dx.doi.org/10.1111/0162-895X.00329

Coleman, J. S. (1990). Foundations of social theory. Cambridge, MA: Harvard University Press.

Hoffmann, P. (1996). The history of the German resistance 1933-1945. Canada: Mcgill-Queen's University Press.

Huddy, L., \& Khatib, N. (2007). American patriotism, national identity, and political involvement. American Journal of Political Science, 51, 63-77. http://dx.doi.org/10.1111/j.1540-5907.2007.00237.x

Jupp, V. (1996). Documents and critical research. In R. Sapsford, \& V. Jupp (Eds). Data collection and analysis. London: Sage.

Jupp, V., \& Norris, C. (1993). Traditions in documentary analysis. In M. Hammersley, (Ed.), Social Research: Philosophy, Politics and Practice. London: Sage.

Nathanson, S. (1989). In defense of “moderate patriotism”. Ethics, 98, 535-552. http://dx.doi.org/10.1086/293096

Oldenquist, A. (1982). Loyalties. Journal of Philosophy, 79, 173-193. http://dx.doi.org/10.2307/2026219

Rebhun, U., \& Waxman, C. I. (2003). Israel in the early twenty-first century: Challenging internal and global developments. Israel Affairs, 9, 1-16. http://dx.doi.org/10.1080/13537120412331321503d

Rothi, D. M., Lyons, E., \& Chryssochoou, X. (2005). National attachment and patriotism in a European nation: A British study. Political Psychology, 26, 135-155.

http://dx.doi.org/10.1111/j.1467-9221.2005.00412.x

Schaar, J. H. (1981). The case for covenanted patriotism, legitimacy in the modern state. London: Transaction Books.

Schatz, R. T., Staub, E., \& Lavine, H. (1999). On the varieties of national attachment: Blind versus constructive patriotism. Political Psychology, 20, 151-174. http://dx.doi.org/10.1111/0162-895X.00140

Shirer, W. (1964). The rise and fall of the Third Reich. London: Pan Books.

Slater, D. (1998). Analyzing cultural objects: Content analysis and semiotics. In C. Seale (Ed.), Researching Society and Culture. London: Sage.

Somerville, J. (1981). Patriotism and war. Ethics, 91, 568-578. http://dx.doi.org/10.1086/292271

Strauss, A. L., \& Corbin, J. M. (1998). Basics of qualitative research: Techniques and procedures for developing grounded theory. Thousand Oaks, CA: Sage.

Tenet, J. (2007). At the center of the storm-My years at the CIA. New York, NY: Harper Collins.

Tice, S. M. (2008). Lebanon. Journal of Mine Action, 12.1. http://maic.jmu.edu/journal/12.1/cp/lebanon/lebanon.htm

Viroli, M. (1995). For Love of Country. Oxford: Clarendon Press.

Wilson, J. (2005). The politics of truth. New York, NY: Carroll \& Graf. 